\title{
Progressive Dissenter: Herbert Hoover's Opposition to Truman's Overseas Military Policy
}

Donald J. Mrozek

ON DECEMBER 20, 1950, HERBERT HOOVER addressed the nation over the Mutual Broadcasting System radio network. His speech challenged the overseas policies of the Truman Administration and heralded a conservative Republican victory for 1952 . Millions listened to Hoover's speech, and it received much attention in national publications. Hoover called for withdrawal of U.S. ground troops from Europe, and demanded recalculation of the relationship between U.S. interests overseas and the policy approved to secure them. Time characterized Hoover's ideas as resurgent isolationism, "ripping off its winding sheet and making loud speeches-and attracting crowds of listeners." Newsweek suggested that Hoover was rejecting the internationalism that had been developing in Congress at least since the start of World War II. U.S. News and World Report somewhat more sympathetically recorded wide-ranging popular approval for Hoover's ideas that contrasted sharply with hostility among public officials. His words were circulated through Vital Speeches of the Day, and Hoover reprinted the message several times. ${ }^{1}$

'See Herbert Hoover, "Our National Policies in This Crisis," broadcast on December 20, 1950, reprinted in Vital Speeches of the Day, XVII, (January 1, 1951), 165-167. Also see Times, LVII, (January 1, 1951), 9-10; Newsweek, XXXVII, (January 1, 1951), 10-11; U.S. News and World Report, XXX, (January 12, 1951), 20-21, and XXX, (January 19, 1951), 16-17 which sharply differentiate among the positions of Truman, Taft, and Hoover. U.S. News and World Report. XXX, (January 12, 1951), 21 presented a report on constituent mail received by Senators and Congressmen concerning Hoover's proposal. The mail favored Hoover by an overwhelming margin. 
Why did people pay attention to this repudiated former president-a reminder as much as a survivor of the ashes of his own era? In part, it was because Hoover had managed to salvage much since the electoral debacle of 1932 . He had returned in an advisory capacity to study food distribution and international relief programs, areas in which he had registered some of his most conspicuous and applauded successes. ${ }^{2}$ In the post-war era of permanent mobilization in which civilians were to contribute to an elusive "national security," a supposedly bipartisan Washington sent out its call for Hoover to join the swelling ranks of the new "soldiers of freedom," the cold warriors. With Hoover so long shorn of command and political support, an invitation to him surely seemed safe.

Yet Hoover's speech in 1950 broke away in a new direction. It attracted attention not only because it deviated from Truman's policy but because it provided alternatives to the criticism of that policy by Robert Taft. After Hoover called for the removal of American troops from Europe and for a virtual termination of American aid to the continent (a call that he later withdrew), Taft was reported as being only in "general agreement with a lot of Hoover's speech" and as agreeing "with many of the general principles he states." By contrast, Senate Republican floor leader Kenneth Wherry of Nebraska proclaimed: "He exactly expressed my sentiments." As Time reported, "Indiana's $100 \%$ Isolationist Homer Capehart rejoiced: 'I agree with him 100\%.' " Taft's statement was grudging support indeed in the face of Wherry's and Capehart's enthusiasm. ${ }^{3}$ In any case, Taft's position was already compromised. His role as a Truman critic was jeopardized by his political ambitions and by his "bipartisan" participation in White House conferences designed to yield approval of administration policies. He voted in favor of the United Nations-an agency that Hoover found dubious in origin and damaging in ef-

${ }^{2}$ Hoover's advice was not merely offered but solicited. See Harry S. Truman, Memoirs, I, Year of Decisions (Garden City, N.Y., 1955). Also see Thomas G. Paterson, Soviet-American Confrontation, Postwar Reconstruction and the Origins of the Cold War (Baltimore, 1973), 82, 87, 92-93, 244.

${ }^{3}$ Others agreeing with Hoover's ideas were former Ambassador Joseph P. Kennedy and Senator Styles Bridges. See Kennedy, "Present Policy is Politically and Morally Bankrupt," Vital Speeches of the Day, XVII, (January 1, 1951), 170 173; Bridges, "Blueprint for Victory," Vital Speeches of the Day, XVII, (February 15,1951$), .265-267$. 
fect. He voted for the North Atlantic Treaty-the promissory note that Hoover feared. Taft's support of NATO made his opposition to Truman's domestic policies ineffectual. The dramatic confrontation that Hoover and his sympathizers had with the Truman Administration overshadowed the disagreements that existed between Hoover and Taft. ${ }^{4}$

Hoover's closest intellectual ally was probably Douglas MacArthur. For MacArthur had complained of Truman's asking for a new kind of military loyalty - to the presidential administration rather than to the nation. Hoover rejected a comparable form of political loyalty in which all ideology, principles, and beliefs were finally hostage to the demands of international policy and national security. In his relentless application of principles to politics, such as he exhibited in his handling of the problems of the Depression, Hoover resembled not Taft, but his mentor Woodrow Wilson. ${ }^{5}$ The coherence of his policies and his unwillingness to modify them flowed from a dogmatism that made him the last of the great Progressives. He viewed the Roosevelt years as an aberration that distorted the relationships among domestic and international policies. Like the politicians and statesmen of the Progressive era, Hoover believed that foreign commitments were manifestations of the internal workings of the state. The country's domestic policies ought never to be affected by foreign pressures. In this way, Hoover became the great preacher of the American creed amid the rubble of Progressive ideology. One of the few who challenged the very structure of the new order, Hoover also rejected what it produced. He criticized international alliances and the mobilization at home that contributed to an emerging military-industrial complex.

Hoover's speech was a call to arms for many conservatives who had languished in futile hostility during the era of Franklin Roosevelt, first overwhelmed by the Great Depression and then used but not heeded in World War II. He sought to capitalize on the

${ }^{4}$ For a clear delineation of differences among Truman, Taft, and Hoover, see U.S. News and World Report, XXX, (January 12, 1951), 20-21. A general study of Truman's approach to defense is Donald J. Mrozek, "Peace Through Strenth: Strategic Air Power and the Mobilization of the United States for the Pursuit of Foreign Policy, 1945-1955" (Ph.D. dissertation, Rutgers University, 1972), especially Chapters 4-7.

'For a demonstration of Hoover's sympathy with Wilson's ideas, see Herbert Hoover, The Ordeal of Woodrow Wilson (New York, 1958), passim. 
unpopularity of the Korean War to reverse American overseas policy. In the process, ironically, he helped create a climate of political opportunity in which General MacArthur became involved in the controversy that ended with his removal from command in Korea; liberal cold warriors pressed for greater commitments to European defense; and Truman confirmed the dominance of the executive branch in military and foreign affairs. Given this record of results so at odds with his intentions, Hoover assumes significance as a popular archaism-a Progressive conscience calling for battle against the forces of post-Rooseveltian politics. The campaign to break Truman's overseas military policies was a move to vindicate and restore the political economy swamped by the New Deal and World War II.

The political origins of Hoover's assault on Truman's military policies rested in hostility to the grand mechanism of political bipartisanship. He considered this effort to build a national consensus behind the administration both fraudulent and subversive, and he believed that it would end in a dictatorship of the executive branch. From the middle of 1950 , Hoover solicited analyses outlining the evils of bipartisanship. His research aide Arthur Kemp urged him to depart from the Republican National Committee's policy of general support for the war effort because it required silence about the administration's foreign policy. He pointed to Dean Acheson's comment on May 1, 1950 that "there is no longer any difference between foreign questions and domestic questions." "If Republicans sincerely differed with Democrats over domestic policy and the nature of American society, collaboration in international affairs was impossible. Similarly, the choice of programs overseas must always take into account their impact within the United States.

On July 7, 1951, Hoover sent a memorandum to Senators Homer Ferguson and Kenneth Wherry and to columnist George Sokolsky indicating that the prerequisites for a constitutionally

${ }^{6}$ Memorandum of information from Arthur Kemp to Herbert Hoover (undated; by context, late 1950); Papers of Herbert Hoover (Hoover Papers), Herbert Hoover Presidential Library, Post-Presidential Subject File, Foreign Policy-General folder. For Truman's views, see Truman, Memoirs, II (Garden City, N.Y., 1956). Also useful is the insightful essay of William Appleman Williams, "What This Country Needs . . .," reviewing Gene Smith, The Shattered Dream: Herbert Hoover and the Great Depression, in The New York Review of Books, (November 5, 1970), 7-11. 
viable bipartisanship were lacking. "Present-day administrations," he noted of both Truman and Roosevelt, "avoid the spirit of the Constitution by making 'agreements,' 'Joint Declarations,' 'doctrines' or settlements under the cloak of the United Nations which detour the Senate's advice and consent." Hoover denied that "the employment of Republicans by the State Department" made these actions bipartisan since they were "not acting under the authority of the Republican members of the Congress."'

By November 8, 1951, Hoover had become even more hostile to collaboration with Truman and the Democrats; and he opposed the government's policy in Korea despite his advocacy of military support for Chiang Kai-shek. In draft material for further advice to Republican leaders and for use in public statements, Hoover declared: "The whole idea of a bipartisan foreign policy is the negation of a fundamental American freedom." The party out of power was to serve as a "check and balance" on the party responsible for action. Distressed at the development of American politics from 1933 and into the Korean War, Hoover lashed out against the uncritical acceptance of foreign policies and suggested that loyalty to the nation's war effort did not require allegiance to Truman's objectives and methods:

Bi-partisanship is/means one party. That is the basis of Communist organization. The whole recent history of bi-partnership in foreign affairs is a record of failures for lack of proper ventilation and criticism ... Even in war . . . foreign political policies outside of military action should be the scene of full criticism or we will make more gigantic political mistakes such as destroyed the hope of peace after World War II.*

Again the former president argued that the Constitution was under fire, stating that the administration had violated the document by going to war in Korea "under the most specious reasoning." The smaller issues, even one as difficult as the Korean War, merely illustrated the administration's disinterest in the Constitution and the network of American values for which it was presumed to stand.

The Korean War revealed the practical consequences that lay

"'Confidential Memorandum on the Essentials of Bi-Partisan Foreign Policy," from Herbert Hoover to Homer Ferguson, Kenneth Wherry, and George Sokolsky, July 7, 1951; Hoover Papers, Public Statements, Tab 3298.

'Draft material for "Confidential Memorandum ..." of July 7, 1951; Hoover Papers, Post-Presidential Subject File, Foreign Policy-General folder.

'Ibid. 
in store for the nation if it continued to violate tradition in determing its international program. The war forced political leaders to question the efficacy of the available peace-keeping machinery, and it confirmed pro-Hoover factions in their alienation from the United Nations as it currently functioned. It was futile, as they saw it, to preserve the organization unless it could serve as the political basis for united forceful action to protect American interests. The Korean War also revitalized their old arguments: the need to prevent a militarization of the society, the impossibility of supporting a permanent war economy, the danger of alliances that entangled without advantage, the superiority of air power, and the disadvantages of land warfare. The war gave dissidents a chance to capitalize on public distress over international affairs and disaffection with Truman in particular. Hooverites contemplated more than a showdown with the Soviet Union and its allies in the United Nations-they sought a showdown between the United States and its own allies. ${ }^{10}$

On July 20, 1950, Hoover wrote to Senator Ferguson: "I would prefer that the non-Communist world be absolutely united, but, alternatively, the United States should know where we stand." He urged that member states of the United Nations be forced to recognize China, North Korea, and the Soviet Union as aggressors and that the United States subsequently withdraw from military action beyond the western hemisphere. He thus expressed his resentment that Washington's allies hesitated to respond to the crises that the United States government took so seriously. ${ }^{11}$ In a speech on July 30 , Hoover demanded that the United Nations be "reorganized without the Communists in it" so that "the United States would be a part of a phalanx, and not a single spear." This would allow at least "partial mobilization of non-Communist nations." The return of the Soviet Union to the United Nations would mean that they would "propose some device which will divide the United Nations." Even this matter would have been less serious if the western Europeans had been better prepared for a vigorous military self-defense. But "West-

${ }^{10}$ One could argue that they also sought a showdown within the United States as well by challenging the genius of the Truman Administration's program.

"Herbert Hoover to Homer Ferguson, July 20, 1950; Hoover Papers, Public Statements, Tab 3242. 
ern Europe outside of Britain has no will to fight a general war with Russia," even though their own preparedness would probably preclude such a war. "Nor do they have the will to adequately prepare." 12

Truman administration officials had elaborated a rationale for the United Nations that was based on arrangements between the Soviet Union and the United States made toward the end of World War II. Truman and his advisers, Clark Clifford, and George Elsey, had not viewed the United Nations as an organization capable of creating peace when the great powers differed. Rather it was intended to serve as a vehicle through which the great powers, having already privately resolved their disagreements, could coerce the smaller states to police themselves within the guidelines supplied by the great powers. The failure of this system stemmed from the inability of the Soviet Union and the United States to compose their differences in private. ${ }^{13}$ Hoover emphasized this failure, and his associates saw contradictions between the "great power" politics of World War II and bi-polar confrontation in the "Cold War."

The Korean War created a climate for a showdown among Americans on Asian as well as European policies. On June 27, 1950, Arthur Kemp gave Hoover an extensive digest of reports published by the State Department implying that the United States' interest in the Far East remained strong. "Action [in Korea]," Kemp emphasized, "has put Truman and Acheson on the spot." 14 Here was an opportunity to break the control of foreign and military policy by a liberal elite. ${ }^{15}$ As the administration's response to the war developed, pro-Hoover elements grew angry at what they considered excessive reliance on U.S. forces and resented their failure to make an effective political dent on the Truman-Acheson policies. On September 14, 1950, Kemp reported to Hoover: "As of July 27, 1950, the only fighting forces of

${ }^{12}$ Off-the-record speech at the Bohemian Club, July 30, 1950; Hoover Papers, Public Statements, Tab 3242.

${ }^{13}$ For the attitudes of Truman and his advisers on the role of the United Nations, see Mrozek, "Peace Through Strength ....," pp. 167-172.

${ }^{14}$ Arthur Kemp to Herbert Hoover, June 27, 1950; Hoover Papers, Post-Presidential Subject File, Foregin Policy-General folder.

${ }^{15}$ See foreign policy memorandum from Arthur Kemp to Herbert Hoover, (undated); Hoover Papers, Post-Presidential Subject File, Foreign Policy-General folder. 
any consequences $[$ sic] engaged in the Korean War were American." ${ }^{16}$ The danger was now serious enough that United States commitments in Asia prefigured what might happen in Europe. It was certainly not true that the Hooverites wanted to desert Asia. They wanted Asians to stabilize the conditions in which American interests could easily be protected; much of their support for Chiang Kai-shek stemmed from his evident willingness to be an active ally-a willingness that contrasted sharply with the mood of the Europeans.

The pattern of military problems around the world cast doubt on the value of sending American troops to fill out the prospective divisions of NATO. Hoover's own opposition to "troops for Europe" was simply a manifestation of his unchanging Wilsonian liberalism, which has more commonly been called "conservatism." Doubting the sincerity of the Europeans, the former president questioned their ability to use properly any short-term American troop commitment. On May 6, 1950, he sent a memorandum to Senator Wherry concerning the "Military situation in America and other countries relative to impending war." Hoover expressed irritation that "at least one of the major European alliance powers is decreasing its debt while ours increases in order to subsidize them." This had to stop. With its nuclear monopoly gone, the United States could not hope to arm "any effective part of these $160,000,000$ people in Western Europe-to say nothing of the $500,000,000$ in South Asia." The conclusion was simple: each country must contribute to its own defense. "The time has come," Hoover summarized, "when we should find out beyond any question of a doubt whether the Nations of Western Europe and Southern Asia are willing to do far more themselves for their own defense." ${ }_{17} \mathrm{He}$ and his sympathizers wanted Germany and Japan rearmed and Franco's Spain allowed to join NATO.

But these opportunistic shifts in American policy would not suffice to ensure peace under the status quo. "The real question," Kemp summarized in a draft for Hoover, "is the extent and nature of the 'self-help' which the nations of Western Europe agreed

${ }^{16}$ Arthur Kemp to Herbert Hoover, August 14, 1950; Hoover Papers, PostPresidential Subject File, Foreign Policy-General folder.

17" Confidential Memorandum to Senator Wherry Concerning the Military Situation in America and Other Countries Relative to Impeding War," from Herbert Hoover, May 6, 1950; Hoover Papers, Public Statements, Tab 3224. 
to provide" in their commitment to NATO. Kemp denied John Foster Dulles' assertion that the United States was bound under the North Atlantic Treaty to rescue the western European states under any circumstances. This denial was more than an attempt to limit American responsibilities in NATO. It was also an effort to wrest control of policy from the executive branch, particularly the president and secretary of state, and to restore it to Congress as the body most representative of public sentiment. Kemp suggested to Hoover that the American people disagreed with Acheson's assertion that the United States, and its allies in the United Nations, had met the challenge in Korea. "Nor are they willing to accept the meager forces as a definition of the 'fair' contribution of nations other than the United States." ${ }^{18}$ Why should the United States yield to French sensitivity concerning the Franco regime when the French themselves were trying to minimize their contribution to western defense? Even more important, why should the United States persist in spending its resources to defend countries unwilling to help themselves. As prosperity had been "just around the corner" in the early 1930s, provided the individual American followed the urgings of Hoover, so would security be just around the corner of the perceived Soviet threat if western Europe and southeast Asia set to work immediately. This was the irreducible objection of the Hooverites to Truman's military program overseas. They denied that terms such as "isolationist, retreatist, and defeatist" described them accurately. Rather the problem was "Europe's ability to help themselves today - not at some indefinite future time." ${ }_{19}$

Hoover wanted to retain interests in Europe but believed that they depended largely on a favorable response by the Europeans to American initiatives. Once again, it was the conflict in Korea that occasioned doubts about the value of alliance with Europe. The American commitment in Korea had not sparked a great rallying of forces in western Europe, and the failure of the Europeans to unite swiftly behind the United States struck their

${ }^{18}$ Draft memorandum from Arthur Kemp to Herbert Hoover, (undated; by context, first half 1951); Hoover Papers, Post-Presidential Subject File, Foreign Policy-General folder.

${ }^{19}$ Draft Memorandum, "Possibilities in Reply Speech," from Arthur Kemp to Herbert Hoover, (undated; by context, first half 1951); Hoover Papers, PostPresidential Subject File, Foreign Policy-Opposition Speeches folder. 
critics as low and opportunistic. The ambiguity in the policies of the western European states convinced Hoover to urge public limits to the American commitment overseas.

On November 1, 1950, Hoover delivered a speech before the Military Order of Foreign Wars of the United States in New York City. From General Dwight Eisenhower he received the Award for Outstanding Citizenship. He then proceeded to attack the European defense policies that Eisenhower had helped create. Pointing out that "disarmament flows only from peace, not peace from disarmament," Hoover called for increased defense contributions from the North Atlantic Pact nations. Since "our present projected program will overstrain our economy if continued more than temporarily," the European nations must "call upon their own manpower, their own factories, their own productive resources in far greater dimensions than is at all evident today." Hoover ended by warning that "otherwise the American people must re-form their lines to cover an area restricted to that which we can defend within our own resources. ${ }^{20}$ The nation was not omnipotent and must avoid any effort at manning Europe's defenses unaided.

In reality, offers to cooperate with Europe were disingenuous. Hoover's supporters did not actually believe that the Europeans would arm adequately against a Soviet threat. Arthur Kemp told Hoover that they were in despair after two world wars and that they believed an unopposed Soviet occupation would be significantly less damaging than an active war. In addition, the French feared the Germans, and Communists and Socialists in western European parliaments objected to military alliance with the United States. ${ }^{21}$ In a speech on January 31,1951 , former Kansas governor and once presidential candidate Alf Landon stated: "It seems to me the crucial thing we are up against is the lack of a will to fight for their own freedom in the western democracies." ${ }^{22}$

${ }^{20}$ Speech by Herbert Hoover to the Military Order of Foreign Wars of the United States, New York City, November 1, 1950; Hoover Papers, Public Statement 3259.

${ }^{21}$ Memorandum, "The Reasons Europe Will Not Adequately Arm Against Russia," from Arthur Kemp to Herbert Hoover, (undated; by context, December, 1950); Hoover Papers, Public Statements, Tab 3262.

${ }^{22}$ Speech by Alf M. Landon to High Twelve Club, January 31, 1951; Hoover papers Post-Presidential File, Landon folder. 
Similarly, Senator Knowland told Hoover that Europe was unlikely to meet its requirements and recalled the example of Korea. Knowland asserted that the United States "has put up $90 \%$ of the forces and suffered $90 \%$ of the casualties of the forces furnished by United Nations members." ${ }^{23}$ Hoover concluded that there was "little public belief [in Europe] that there was risk of Russian invasion in the near future." He also believed that the Europeans thought "the opportunities for the Kremlin [were] in Asia and that its face [was] turned East." ${ }^{24}$ Ironically, the same Korean experience that had made "troops for Europe" seem so much more necessary to many Americans made arming against the Soviet Union seem superfluous to many Europeans. ${ }^{25}$ As far as Hoover was concerned, they would simply have to accept the consequences of their own choices. Europe's failure to respond, which Dwight Eisenhower admitted, made its nations seem defeatist and parasitical. Hoover was not about to support an "international dole" that would bankrupt the country and threaten its security without even assuring loyalty among its allies in a prospective crisis.

Hoover's particular objections to the way the Korean War was being managed provided him with a chance to attack the general framework of policy in which it rested. Just as he questioned the efficacy of NATO and the UN, so did he criticize Truman's use of conventional ground forces. Hoover considered ground warfare especially conducive to stalemate. The conduct of the Korean War thus violated his convictions about the predominant importance of air power. Hoover asked Senator Wherry whether General MacArthur had advised Truman on Korean policy, as much to keep watch over MacArthur as to gain ammunition against Truman. ${ }^{26}$ Later he complained to General Bonner Fellers, head

${ }^{23}$ William F. Knowland to Herbert Hoover, February 2, 1951; Hoover Papers, Post-Presidential Individual File, Knowland folder. Knowland excluded South Korean troops from his calculations.

${ }^{24}$ Statement, "The Year Since the Great Debate," by Herbert Hoover, (undated; early 1951); Hoover Papers, Public Statements.

${ }^{25}$ On European defense, see Eisenhower to Robert A. Lovett, December 13, 1951; Eisenhower Papers, Personal Files-Pre-Presidential, Lovett folder. For a general survey of this effort, see David W. White, "The Effect of the Attitudes and Actions of Dwight D. Eisenhower on the North Atlantic Treaty Organization, 1950-1956: (M.A. thesis, Kansas State University, 1973).

${ }^{26}$ Kenneth S. Wherry to Herbert Hoover, September 28, 1950; Hoover Papers, Post-Presidential Individual File, Wherry folder. 
of the Veterans Division of the Republican National Committee, that MacArthur should have followed his advice: "stop and dig in on the short line across Korea-and then use his air force on any armies north of that area." ${ }^{27}$ In this way, air power could also effect a disengagement on the ground that would permit thoughtful diplomatic action, including possible withdrawal from the United Nations operation altogether.

Reviewing the year since he inaugurated the "Great Debate," Hoover set out in detail the defects of ground forces. "If our economy should collapse," Hoover warned, "Stalin's victory would be complete." Therefore "to maintain the economic strength of the United States and to prevent its socialization does not permit our building up great ground armies in addition to overwhelming air and sea forces and supply of munitions to other nations." ${ }^{28}$ The United States might continue to serve as "arsenal of democracy." It could continue to provide "artillery support" through the Air Force and Navy. But other nations would have to supply the infantry. The domestic needs of the United States required it.

Hoover refused to let international concerns dictate the character of American society. Taft's votes on the United Nations and NATO already constituted some compromise with foreign demands. As Hoover saw it, however, to allow the international military situation to dictate the internal structure of the United States and to force the redefinition of its national objectives would be to surrender all that would have been worth fighting for in the first place. For this reason, Hoover attached greater importance to the preservation of the national economy than to the forced construction of international military alliances. Reviewing the events of 1951, when the extraordinary expenses of the Korean War pushed the national military budget to more than $\$ 60$ billion, Hoover asserted that "the outstanding phenomenon is the dangerous overstraining of our economy by gigantic expenditures. ${ }^{29}$ In itself, this view was neither new nor unique to Hoover and his associates. Dwight Eisenhower, himself an object of deep suspicion to the Hooverites, had already warned the Truman Administration to seek "the highest level to which you think these [de-

\footnotetext{
${ }^{27}$ Herbert Hoover to Bonner Fellers, December 3, 1950; Hoover Papers, PostPresidential Individual File, Fellers folder.

${ }^{28}$ Hoover, "The Year Since the Great Debate."

${ }^{29}$ Ibid.
} 
fense] expenditures can go without breaking us internally. . .". Similarly, Secretary of the Army Kenneth Royall had told the president's Air Policy Commission in 1947 that they must find a criterion by which to limit military spending. The difference between what Eisenhower, and Royall, and the Hooverites proposed lay less in dollar-volume than in the duration of the program. Royall had continued his remarks in 1947 to suggest: "I do not think we have approached the absolute limit of what we could spend." After observing the escalation of American involvement in Greece, Turkey, Korea, and the projected military alliances, Hoover was less sanguine and emphasized that inflationary spending would produce disaster in the long run: "A man may carry a load of 300 pounds across the room, but he will break his back if he carries it around the block." ${ }^{31}$ Both Royall and Hoover saw difficulties in long-run over-spending, but Hoover's "long-run" was shorter than Royall's.

The susceptibility of Americans to faulty economic policies was, by extension of its consequences, a military reality. It had resulted, according to Hoover, from decades of conditioning by slogans extolling novelty:

We have had the "New Order," the New Freedom, the New Day, the New Era, and New Outlook, the New Epoch, the New Economy, the New Dawn, the New Deal, the New Religion, the New Liberalism, the New War and several New Foreign Policies.

And the New Testament is too often omitted. After each "New" we have a relapse and take another pill, also labelled "New." ${ }_{32}$

All of these programs, he suggested, deviated from conventional American ideals, guidelines, and wisdom. Most of them, "like the Apples of Sodom, have turned to bitter ashes in our national mouth." He concluded that "our greatest danger is not from invasion by foreign armies. Our dangers are that we may commit

${ }^{30}$ Testimony of Dwight Eisenhower, November 11, 1947 (revised version); Records of the President's Air Policy Commission, Harry S. Truman Library, Royall folder.

"Hoover, "The Year Since the Great Debate."

${ }^{32}$ Speech at the Bohemian Grove Encampment, by Herbert Hoover, July 18, 1951; Hoover Papers, Public Statements. Among those sharing Hoover's resentment of politico-social novelties were Admiral Richard E. Byrd (Byrd to Hoover, October 29, 1950; Hoover Papers, Public Statement 3262), and K. T. Keller, chairman of the board of the Chrysler Corporation (Keller to Hoover, January 8, 1951; Hoover Papers, Public Statement 3262). 
suicide from within by complaisance with evil." ${ }_{33}$

Because of his complex view on the relationship of domestic and international policy, Hoover found no pleasure in the prospect of an Eisenhower presidential candidacy. Perhaps Taft had been too slow, too cautious, and too qualified in his commitments. But Eisenhower was a part of Truman's international team. He was the commander and one of the architects of its key alliance with western Europe. On August 2, 1950, Arthur Bliss Lane criticized the general for assisting Truman in lulling "the people of this country into a state of complacency" by "persuading [them] that we are not in a world war today." ${ }^{34}$ As criticism of Truman's handling of the Korean engagement intensified, Eisenhower's political supporters urged that he avoid comment on Asian affairs. Yet Eisenhower formally expressed confidence in the president, much to Truman's pleasure. ${ }^{35}$ During the subsequent weeks of debate over the removal of General MacArthur from command in Korea, Eisenhower remained closely allied with Truman.

To opponents of America's international policies, Eisenhower was the embodiment of Truman's brand of bipartisanship. To them he seemed weak, opportunistic, and unprincipled. Hoover's staff compiled a folder of Eisenhower's statements on major national and international problems designed to expose these flaws. He was styled a friend of the Soviet Union in 1945, saying that "nothing guides Russian policy so much as the desire for friendship with the United States." He was quoted as "urging mobilization at wartime speed after telling Congress the U.S. should more than double its European forces this year by basing six divisions there and boost the total to 12 by the end of 1952. ${ }^{\prime 36}$ [emphasis by staff] In a pre-Convention draft statement, Hoover

${ }^{33}$ Speech at the Bohemian Grove Encampment, by Herbert Hoover, July 28, 1951; Hoover Papers, Public Statements.

${ }^{34}$ Arthur Bliss Lane to Herbert Hoover, August 2, 1950; Hoover Papers, PostPresidential Individual File, Lane folder.

${ }^{35}$ See Harry S. Truman to Dwight D. Eisenhower, April 12, 1951; Eisenhower Papers, Personal Files-Pre-Presidential, Truman folder; Memorandum from Harry S. Truman to W. Averell Harriman, April 24, 1951; Eisenhower Papers, Personal Files-Pre-Presidential, Truman folder.

${ }^{36}$ Staff compilation, "Eisenhower Versus Eisenhower," (undated; by context, Summer 1952); Hoover Papers, Post-Presidential Individual File, Eisenhower folder. 
summarized: "General Eisenhower has at all times, so far as any record shows, been a part of the Truman Foreign Policies." ${ }^{37}$ The evils developing within American society were thus Eisenhower's, as well as Truman's, responsibility. "He cannot criticize inflation, taxes and degeneration of the American economy which are the necessary outcome of the policies he developed and fostered." ${ }^{38}$ Eisenhower had supposedly allowed his estimate of the European situation to take precedence over his understanding of the socio-economic structure of the United States.

A memorandum circulated by Senator Homer Ferguson asserted that the Eisenhower movement "seriously threatens the two-party system." The author compared Eisenhower to Wendell Willkie, stating that both had Democratic backgrounds and that neither represented Republican party principles. As the "price people will have to pay for an Eisenhower victory," the memorandum enumerated "permanent conscription and military service for all young men and women, permanent stationing of American troops in foreign countries, permanent economic and military support of Europe," and "American substitution for the role played by the British Empire in world politics (notwithstanding the fate which that role has visited upon Great Britain)." ${ }^{39}$ The danger was the capture of the Republican Party by the "Military-Internationalist-New Deal group" who could finally transform themselves into "something of a National Liberal Party." ${ }^{40}$ Thus Eisenhower himself was unacceptable because his movement was seen as a constitutional threat and a challenge to the American way of life. It was his particular form of internationalism, and his alleged yielding to foreign over American interests, that Hoover opposed.

In the final analysis, it was Hoover's special definition of American individualism that forced him to oppose Truman's

${ }^{37}$ Draft statement, "The Truman-Eisenhower Foreign Policies," by Herbert Hoover, (undated; by context, pre-Convention 1952); Hoover Papers, Post-Presidential Subject File, Foreign Policy, Truman-Eisenhower folder. The Legal Adviser of the Department of State, Robert A. Low, agreed. See Low to Elsey, September 22, 1952; Papers of George Elsey, Harry S. Truman Library, Dulles folder.

${ }^{38}$ Draft statement, "The Truman-Eisenhower Foreign Policies."

${ }^{39}$ Staff memorandum, "Validity of the Eisenhower Movement Within the Republican Party," transmitted by Homer Ferguson to Herbert Hoover, May 8, 1952; Hoover Papers, Post-Presidential Individual File, Eisenhower folder.

${ }^{40}$ Ibid. 
policies and to resist Eisenhower's presidential candidacy. The creation of a large, permanent military force overseas represented, for the former president, an internationalization of the dole that he had criticized during the tenure of Franklin Roosevelt. The pursuit of the values of American individualism forced him to oppose sending troops to Europe, demanded that he seek the expulsion of communists from the United Nations, and called his attention to political and consititutional questions in the United States. Because Hoover's protest failed, there was no workable alternative to the administration's policy, which left the door open for increasingly elaborate military involvement around the world.

In labeling Hoover an isolationist, Truman's supporters were wrong. To advocate an actively interventionist policy in Japan and Formosa, to support anti-communist activity in Southeast Asia, to encourage the continuation of United States dominance in the Western Hemisphere, and to call for close ties with Britain and coastal Europe hardly constitutes isolation and the adoption of a mere "fortress" posture before the rest of the world. The fact that he could be so characterized merely underscored how far beyond isolationism the entire country had moved. For Hoover, a sensible military program could be defined only in terms of real or clearly anticipated threats. While Hoover's military would thus be basically defensive in concept and function, Truman's military was not only to protect what existed in the world but to achieve what existed only in the imaginations of expansionist planners.

The revolution in methods for expanding American influence that Truman had authorized compelled Hoover to fight the administration's military policy. He did not object to economic and diplomatic penetration of foreign states. As president, he had encouraged it himself. But he rejected the means that Truman had chosen to achieve it, involving the expansion of the nation's armed forces overseas and the ratification of the "Roosevelt revolution" at home. Ultimately, Hoover wished to overturn not merely Henry Wallace's "century of the common man" but also the fatuous global expansionism of Henry Luce's "American century." Hoover was content with an American hemisphere whose lines of communication and trade with other parts of the world remained free and open. For, as he saw it, it was the 
unrestrained generation of new American interests around the world, under the presidency of Truman and the inspiration of his advisers, that endangered the possibilities for imperial growth within the domestic limits of Constitution and tradition.

Heritage of Dubuque-An Architectural View, text by Lawrence J. Sommer, and illustrations by Carl Johnson, is an impressive cataloguing of the buildings of Iowa's oldest city. Johnson's drawings and watercolors of historic edifices and homes, accompanied by numerous photographs, map Dubuque's heritage from the early years, $1830-1860$, up through what is termed "a period of transition," 1890-1930. Early crude log structures gave way to more sophisticated buildings made of materials native to the area: wood, stone, sandstone, and brick. The final chapter in the book discusses progress and plans toward restoring certain landmarks in the city. Sommer feels that "perhaps the most striking achievement has been the restoration of the Orpheum Theater. It is once again one of the most handsome buildings on Main Street."

As in almost all older American cities, Dubuque can count many old homes, churches, schools, etc. lost to parking lots, new office buildings and remodeling projects. Some of the losses were due to "natural disasters," however, like the old town clock building which collapsed on May 25, 1872. A new one was quickly erected the following year. "Today, over a hundred years later, local residents still set their watches by this town clock." It is a sad revelation to see that the once beautiful and spired Illinois Central railroad passenger depot has been reduced over the years to a squat, flat-looking freight terminal.

The Heritage of Dubuque is the Bicentennial project of the First National Bank of Dubuque-with the proceeds going to the restoration of the Orpheum Theater, which will become the Five Flags Civic Center. The book can be secured from the Five Flags Office, Room 622, Dubuque Building, Dubuque, Iowa 52001 for $\$ 12.50$._Ed. 
Copyright of Annals of Iowa is the property of State of Iowa, by \& through the State Historical Society of Iowa and its content may not be copied or emailed to multiple sites or posted to a listserv without the copyright holder's express written permission. However, users may print, download, or email articles for individual use. 